Review

\title{
Food, Energy and Water Nexus: A Brief Review of Definitions, Research, and Challenges
}

\author{
Hamdi Abdi ${ }^{1, *}$, Maryam Shahbazitabar ${ }^{1}$ and Behnam Mohammadi-Ivatloo ${ }^{2,3}$ \\ 1 Electrical Engineering Department, Engineering Faculty, Razi University, Kermanshah 67149-67346, Iran; \\ mshahbazitabar@yahoo.com \\ 2 Faculty of Electrical and Computer Engineering, University of Tabriz, Tabriz 51666-16471, Iran; \\ mohammadi@ieee.org \\ 3 Department of Energy Technology, Aalborg University, 9200 Aalborg, Denmark \\ * Correspondence: hamdiabdi@gmail.com
}

Received: 25 September 2020; Accepted: 17 November 2020; Published: 23 November 2020

\begin{abstract}
Vast expansion in consumption is leading to natural resource scarcity and global warming. The integrated management of natural resources, such as food, energy, food (FEW) as one of the most important aspects has been proposed as a solution to meet these challenges. The FEW nexus is a world-wide solution for simultaneously assessing the development and implementation of various approaches focusing on energy, water and food security, sufficiency. This approach is intended to foster sustainable development and improve the quality of life of communities while preserving the natural, human and social capital, address the long-term sustainability challenges and protecting all-natural resources. This paper tries to review some recent research on this topic. For this purpose, first, we describe some facts about demand growth and exponential consumption in these three areas, with emphasis on presented statistics. Then, the most critical research published in this field is reviewed, considering that it took a decade or so before that the original idea was introduced. The most important policymakers of this emerging concept, including committees and conferences, and finally significant challenges and opportunities to the implementation along with future insights, are addressed.
\end{abstract}

Keywords: nexus; food; energy; water; greenhouse gas emission

\section{Introduction}

The food-energy-water (FEW) nexus is known as the significant interconnection between three essential resources for human societies. FEW is an extended concept that is introduced to overcome and manage resource scarceness challenges. The nexus target is to establish effective tradeoffs and synergies between energy, water and food, considering cross-sectoral policies, environmental and social impacts [1]. The FEW nexus implies that the availability of the others may limit constraints or changes of one edge, and implemented solutions in one sector can mainly affect other areas [2,3]. For example, food or energy production is limited by the availability of the water supply. Energy-saving can decrease water consumption, whereas water efficiency growth leads to a decrease in energy, which is used for transition and purification.

As an important note, and based on what is addressed in [4], the perspective of the policymaker determines the method to the FEW nexus. From the perspective of water, energy and food systems are mentioned as the users of the resource, and in the perspective of food and energy, energy and water; water and bio-resources are the outputs, respectively. In addition, each of the three resources affects the others, and ignoring the effects in one resource can have significant impacts on other sources. The main important types of FEW nexus are detailed as energy access and deforestation, 
biofuels (and unconventional gas and oil) production, hydropower, food and irrigation security and desalinization.

Although many definitions were provided on this concept, the reality is that no comprehensive description has yet been adopted by all researchers [5]. In general terms, the definitions provided for this topic can be divided into two parts.

In the first definition, the nexus is defined as the interactions and interconnections among different sectors (or subsystems) considering food, energy and water [6]. In the second definition, which is more general, the nexus is described as an analysis tool or method to quantify the links among the nexus nodes, including food, energy and water [5].

Over the last few decades, cities are getting more populated than about $54 \%$ of the global population [7], and more FEW demands occur. Governments are concerned about FEW sources of scarceness that have effects on several aspects of societies such as community, homes, businesses and industries [8]. This demand growth in cities caused more than $60 \%$ of energy consumption and $75 \%$ of pollution [9]. In addition, it is estimated food, energy and water resources using will be increased by $35 \%, 50 \%$ and $40 \%$, respectively, by 2030 [10]. The exponential growth of the population considering limited supplies is simulated, and horrible resource scarcities are concluded [11]. Consequently, the increasing rate in population caused more food requests, energy consumption, and increasing greenhouse gas (GHG) emissions because of relying on food chains on water and energy. Although the different natural and fresh products such as wheat, rice, vegetable, etc., need different adequate water by where and when they have cultivated, the canned and frozen food has relied on water supply directly and indirectly.

Water sources are the pillar for both modern and traditional societies. Water is used for irrigation, electricity and heat generation, fuels for transportation and packaging. The authors of [12] implied that total energy utilization in the water section has currently surpassed $800 \mathrm{TW} / \mathrm{h}$, and it is predicted to increase up to $80 \%$ until 2040 . Indoor agriculture (IA) as a system without farmland is a way to significant energy savings and overcome water wasting (e.g., rooftop greenhouses) [13].

Based on the Energy Information Administration (EIA) reports, the global energy demand will increase by about $50 \%$ from 2018 to 2050 [14]. In addition, the energy use in the industrial sector, including mining, refining, agriculture, manufacturing and construction, increases more than $30 \%$ between 2018 and 2050 as the demand for goods increases. Furthermore, electricity generation will be increased by $79 \%$ between 2018 and 2050. This is while energy generation is a key contributor to air pollutant emissions too. GHG emission, raised by the widespread application of fossil fuels in both the transportation and power generation sector, is the main concern due to environmental issues and the global warming effect. In this way, the climate change raised by GHG emissions, and created by the prevalent fossil fuel usage in both transportation and power generation, is widely accepted as a real-world menace that has potentially severe effects on human health. Hence, one of the critical concerns is moving from fossil fuels to other nonconventional renewable sources of energy, such as wind and solar [15]. As shown in Figure 1, a major contributor to GHG emissions is heat and electricity extraction from oil, coal and natural gas [16]. Even though the nexus concept has been introduced in recent decades, it has evoked the eagerness of researchers all over the world [17].

Preserving the natural resources and preventing their destruction in the three fields of food, energy and water requires a comprehensive framework that considers not only the individual security of the three systems but also their interactions and interdependencies [18]. Figure 2 shows a conceptual model in this regard. As an important note, environmental concerns have become an important security issue in international relations and have been addressed by governments and policymakers. Due to the seriousness of environmental issues and related climate change, this issue can be considered as an effective variable in various conflicts. Climate changes have affected not only the natural habitats but also the social structures of communities and increased the likelihood of violent conflicts [19]. In addition, they endanger international peace and security and affect environmental justice. 


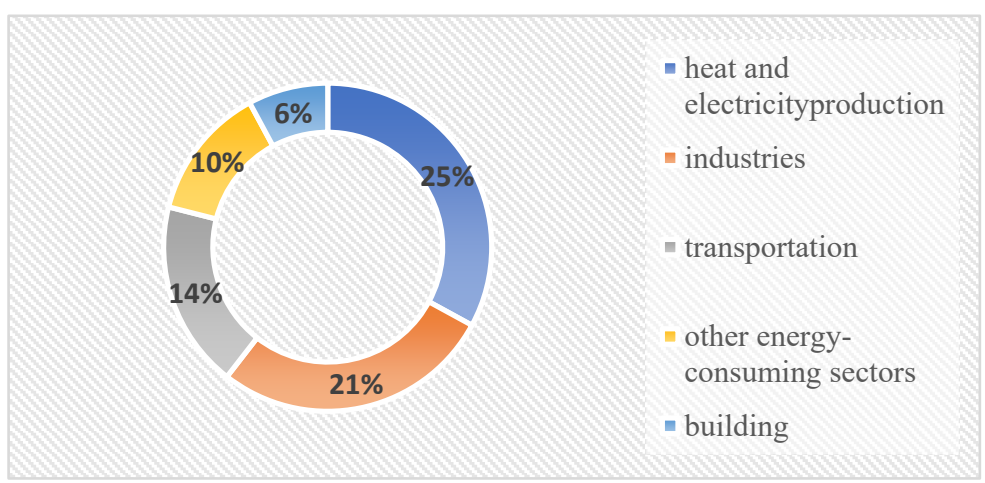

Figure 1. Major contributors to greenhouse gas (GHG) emissions [16].

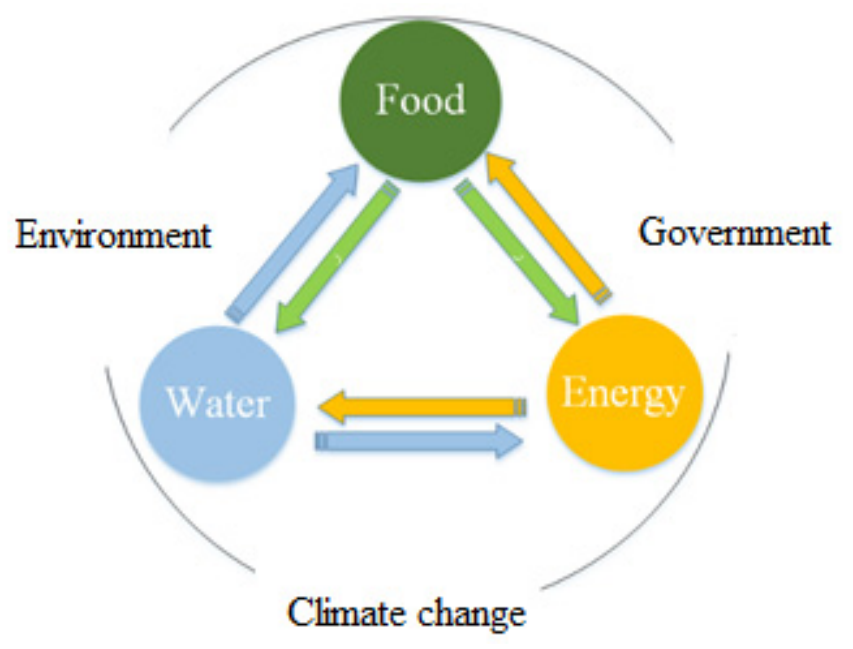

Figure 2. A conceptual model of food-energy-water (FEW) nexus.

Some of the most critical connections between these three systems are as follows:

- Water is needed for energy generation, primarily hydroelectric power plants, biofuels, etc.;

- Water is needed for food production, various nutrients, agricultural irrigation, livestock systems, etc.;

- The energy required for food production, all stages of food preparation including harvesting, transportation, preparation, packaging systems, etc.;

- The energy required in the water sector: water and wastewater purification and desalination, water distribution systems, agricultural irrigation, electricity generation, etc.;

- $\quad$ Nutrition for electricity generation: providing healthy food for personnel and operators in the industrial, economic, etc.

Table 1 provides an example of the energy, food and water security nexus.

Table 1. Energy, food and water nexus [18].

\begin{tabular}{lll}
\hline \multicolumn{1}{c}{ Food Security } & \multicolumn{1}{c}{ Energy Security } & \multicolumn{1}{c}{ Water Security } \\
\hline Food availability & Supply of energy on demand & Water availability \\
Equal access to food & Physical accessibility of supply & Water health \\
Optimal water utilization & Supply to satisfy demand at a stable rate & Cost-effectiveness of water \\
\hline
\end{tabular}

\section{Literature Review and Real Case Studies}

Since the Bonn conference (2011) with "The Water, Energy and Food Security Nexus-Solutions for the Green Economy" title was held, several numbers of FEW nexus have been published, whereas almost 
300 organizations have formed across the world from 2011 to 2015 [17]. The related search keywords were: two-pronged nexus approach "energy-food" (EF), "energy-water" (FW), three-pronged nexus approach "energy-food-water" (EFW) or multipronged such as "energy-food-water-land" (EFWL). In ref. [17], by investigating 37 projects, it was described that $6,11,12$, and 8 projects $(16 \%, 30 \%, 32 \%$ and $22 \%$ ) of them had a close linkage with FW, FEW, WE and FEWL nexus, respectively, which is demonstrated in Figure 3.

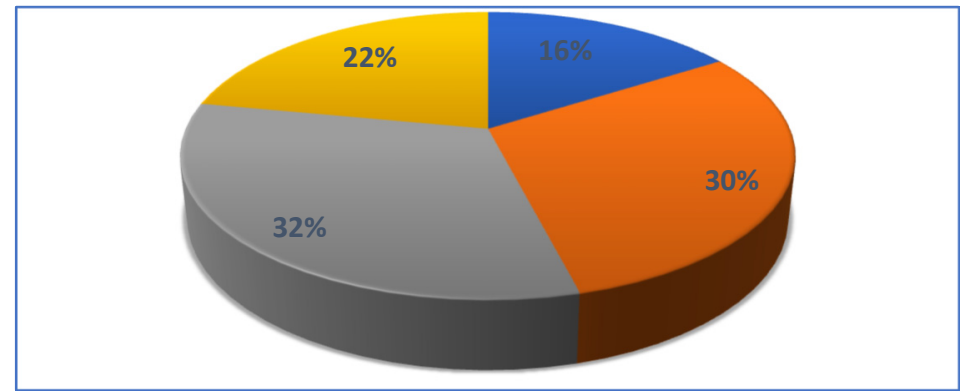

Figure 3. The percentage share of investigated projects in different nexuses in [17].

In another viewpoint, it is claimed every element in this nexus may be a user or source, whereas the taken perspective will affect the policy design. For example, from a water view, energy and food systems are inputs [20], while water and energy are inputs from a food perspective studies [21,22]. Water consumption control considering water supply efficiencies is proposed in food production simultaneously. Projects on energy-water nexus ranged from water for energy to energy for water. Biofuel using water and hydropower generation are examples of water demand for energy production. Energy consumption examples included water pumping in food generation and electricity consumption in water purification.

In [23], a comprehensive survey on modeling and optimization techniques for energy hubs, as one of the basic concepts of future energy systems, is presented. The authors tried to investigate the impacts of distributed energy resources (DERs) in the presence of a smart grid by addressing the economic and environmental considerations. In addition, they mentioned plug-in hybrid electric vehicles (PHEVs), multiple energy flow carriers with storage and the hydrogen economy as a simple EW nexus. Different technologies, including combined heat and power (CHP), solar, wind, hydrogen and different energy vectors, including electrical, natural gas, bio and hydrogen, are addressed in this study.

A sample multi-energy nanogrid (MEN) considering both economic and low-carbon objectives in islanded and grid-connected modes was optimized in [24] by applying linear programming. The case study of a single-family house of $200 \mathrm{~m}^{2}$ located in Italy was mentioned, and the TRNSYS as the dynamic simulation software is used. The proposed MEN consisted of micro CHP, a boiler and a PV in the generation section, a heat pump and a chiller in the conversion part and some batteries and thermal energy storage (TES) devices for heat and cool in the storage section. This system delivers the electricity, heat and cooling to the end-user.

In [25], a literature review on using nonconventional resources for water and the other alternatives that could be applied to increase food security in water-scarce countries is presented. For this goal, some selected solutions, including the rainfall-runoff water, the desalinated seawater and highly brackish groundwater, marginal-quality water resources and captured by water harvesting, are addressed. In addition, the opportunities contributing to food security in water-scarce countries are detailed among the physical transportation of fresh water and food imports and the "virtual water" nexus. As a result, this reference claims that there is no choice for water-scarce countries to supply the needed food by applying either the nonconventional or conventional water resources available within their boundaries. In addition, this ref. forecasted that many water-scarce countries should continue to import food. However, they can rely on producing a proportion of their requirements domestically. 
Reference [26] classified the main factors to drive food production and agricultural growth in India as access to utilizable water resources and arable land. This reference investigated the water management and food security challenges that lie in the mismatch between agricultural water demand and water availability.

In [27], the training needs and limitations of the oil palm fruit processor in Nigeria by applying a two-stage sampling method to select 160 households included in palm oil extraction activities among the study case are investigated. The data were collected by using an interview and were investigated using both training needs and descriptive analyses.

Both the water needed to run the energy sector and energy applied to the water sector in Spain are investigated in the WE nexus [28]. It considers different policy objectives for expected renewable energy and biofuels resources.

In [29], the role of nonconventional waters (e.g., desalinated and recycled waters), in arid areas, like the city of Kashan, Iran, was focused as the alternative resource of water. This research investigated the costs and environmental impacts of the energy by using these alternative resources. It was claimed that the maximum capacity of the nonconventional water is not necessarily the optimal point.

Different methods of using solar energy for getting usable water from seawater and wastewater were reviewed in [30]. For that goal, the usage of sunlight for water treatment is divided into desalination, or solar distillation, solar detoxification, solar disinfection, and a brief overview of these topics are discussed.

Scott et al. [31] demonstrated the impacts of the coupling of WE at multiple scales. They investigated three WE nexus cases in the US, located in Central, Eastern, and Western regional stakeholder priorities. They stated that localized problems and challenges could be diminished when considered from broader perspectives; meanwhile, regionally significant challenges are not prioritized locally.

In [32], the governing formulation for WE on catchment scales and long-term time are presented in the form of partial differential equations in a three-dimensional space. As the authors claimed, the presented solution is a useful technique to analyze the impacts of land-use and climate changes on the hydrologic cycle.

Hang et al. [33] developed some process systems and engineering tools combined with the nexus concept by using exergy for the design of local generation systems. The suggested framework comprised an optional preliminary design stage combined with a simultaneous design stage based on mathematical optimization. Furthermore, potential interactions between different subsystems were modeled. The suggested method was simulated on a sample WEF at an eco-town in the UK.

The food waste within the FEW nexus is mentioned in [34], and the differential FEW impacts of producing uneaten food and managing food loss and waste were parsed. In addition, different food waste management techniques are classified as landfilling, waste prevention, anaerobic digestion, composting, and incineration. Furthermore, the concept of the "food-waste-systems" technique to optimize resources within the FEW nexus was addressed, and relevant definitions and opportunities were detailed.

The current research needs for understanding the FEW nexus and the relevant implementing solutions in terms of technologies, infrastructures, and policies were discussed in [35]. The main goal of this work is to achieve sustainable development by presenting some guidelines for hydrologists, water resources engineers, economists and policy analysts.

In [36], by focusing on the global value chains (GVCs) concept, the transnational inter-regional input-output approach is used in a tele-connected WEF nexus of East Asia was assessed. For this purpose, China, South Korea and Japan countries were selected as case studies, and different strategies were investigated.

Authors of [37] presented a new framework for optimal short-term scheduling of WE nexus to minimize total electricity cost and seawater desalination considering different constraints. For this purpose, the proposed model was solved by the mixed-integer nonlinear programming (MINLP) using a general algebraic mathematical system (GAMS) software to minimize differed objective functions. 
In addition, an interconnected WE nexus, composed of thermal generation units, combined potable water and power (CWP) units, and desalination only processes, is investigated in [38] by using the GAMS software to schedule the water-power hub networks in the presence of the hydro units.

A new technique for the day-ahead optimization of integrated heat-water-electricity systems to optimize different objective functions is proposed in [39], considering a real-time demand-side management strategy. In addition, the impacts of electric vehicle participation are mentioned. The suggested mathematical formulation was solved in the GAMS optimizer using the branch-andreduce optimization navigator (BARON) tool.

Authors of [40] presented a useful review of demand response strategies applied to the industrial section as well as in the wastewater treatment plant operation.

Peri et al. [41] have investigated the financial impacts of WEF nexus among the volatility spillovers by applying a multivariate generalized autoregressive conditional heteroskedasticity $(\mathrm{GARCH})$ technique. The authors have used the daily data and have applied two indexes of the S\&P Goldman Sachs (GS) commodity index for modeling the food and energy variable. In addition, the equity index is used to model the water variable.

In [42], considering an EW nexus, the impact of agriculture and energy prices on the stock performance of the water industry, by applying a multifactor market model, is investigated in a case study that considers the economic and financial crisis during 2008. The results were confirmed in three steps, including a GARCH approach, a rolling OLS and the state space representation estimating Kalman filter.

In addition, modeling the possible interactions between the future energy prices in European Union Allowances (EUA) is addressed in [43] by applying a nonlinear co-integration dynamic method through $\mathrm{CO}_{2}$ futures and Brent.

Table 2 reviews some research information on this context.

Table 2. Brief information about studies in different nexus.

\begin{tabular}{cllll}
\hline Ref No. & Nexus & \multicolumn{1}{c}{ Aspects of Goal } & \multicolumn{1}{c}{ Description } & Year \\
\hline [23] & WE & $\begin{array}{l}\text { A review on economic } \\
\text { environmental and } \\
\text { emission issues of EH }\end{array}$ & $\begin{array}{l}\text { Different technologies and energy carriers } \\
\text { are investigated }\end{array}$ & 2019 \\
\hline$[24]$ & WE & $\begin{array}{l}\text { Economic and } \\
\text { Environmental }\end{array}$ & $\begin{array}{l}\text { Micro CHP, boiler, PV, heat pump, chiller } \\
\text { batteries and TES devices }\end{array}$ & 2020 \\
\hline [25] & WF & Environmental & $\begin{array}{l}\text { Nonconventional water sources for achieving } \\
\text { food security in arid countries are used }\end{array}$ & 2007 \\
\hline [26] & WF & $\begin{array}{l}\text { Environmental, social, } \\
\text { economical }\end{array}$ & $\begin{array}{l}\text { Pro-rata pricing in farm and public irrigation } \\
\text { systems improves the energy efficiency in } \\
\text { green water; the residual soil moisture } \\
\text { depletion preventing; low water consuming } \\
\text { crops cultivation }\end{array}$ & 2012 \\
\hline [27] & WF & Social, economical & $\begin{array}{l}\text { Expansion and training studies by } \\
\text { stakeholders for palm oil extraction } \\
\text { in Nigeria }\end{array}$ & 2011 \\
\hline [28] & WE & Social, economical & $\begin{array}{l}\text { More efficient ways for irrigation, } \\
\text { urban wastewater menace and the use of } \\
\text { desalinated water }\end{array}$ & 2012 \\
\hline
\end{tabular}


Table 2. Cont.

\begin{tabular}{|c|c|c|c|c|}
\hline Ref No. & Nexus & Aspects of Goal & Description & Year \\
\hline$[31]$ & WE & Environmental, political & $\begin{array}{l}\text { Addressing the methods for coupling } \\
\text { different resources at multiple scales, find out } \\
\text { the obstacle of institutional opportunities for } \\
\text { decision-making }\end{array}$ & 2011 \\
\hline$[32]$ & WE & Economical & $\begin{array}{l}\text { A unique general solution for the mean } \\
\text { annual energy-water balance equation has } \\
\text { been proposed by using mathematical } \\
\text { formulation and dimensional analysis }\end{array}$ & 2008 \\
\hline$[33]$ & FEW & Economical & $\begin{array}{l}\text { Local production system method and extract } \\
\text { optimization model for the } \\
\text { energy-food-water nexus designing in a } \\
\text { local UK eco-town. }\end{array}$ & 2016 \\
\hline [34] & FEW & $\begin{array}{l}\text { Environmental, social, } \\
\text { economical }\end{array}$ & $\begin{array}{l}\text { Addressing the different subsystems for } \\
\text { preventable and unpreventable food waste }\end{array}$ & 2018 \\
\hline [35] & FEW & Economic, political & $\begin{array}{l}\text { Historical efforts in integrated water } \\
\text { resources management (IWRM) have been } \\
\text { applied to present alternatives for } \\
\text { interdisciplinary studies among several } \\
\text { groups with collaboration between food and } \\
\text { energy communities. }\end{array}$ & 2018 \\
\hline [36] & FEW & $\begin{array}{l}\text { Environmental, social, } \\
\text { political, economical }\end{array}$ & $\begin{array}{l}\text { Designing the hybrid FEW connections in } \\
\text { Japan and China to obtain the } \\
\text { interdependencies of hybrid water, hybrid } \\
\text { energy and food extractions with other } \\
\text { sectors in two countries }\end{array}$ & 2019 \\
\hline$[37]$ & WE & Economic dispatch (ED) & $\begin{array}{l}\text { Day-ahead ED, including coupled } \\
\text { desalinated water, power networks in the } \\
\text { presence of compressed air energy storages }\end{array}$ & 2019 \\
\hline$[38]$ & WE & Short-term scheduling & $\begin{array}{l}\text { Short-term planning of desalination water } \\
\text { and thermal units }\end{array}$ & 2019 \\
\hline [39] & WE & Short-term scheduling & $\begin{array}{l}\text { Investigating the impacts of demand } \\
\text { response programs and plug-in electric } \\
\text { vehicles in short term scheduling of a } \\
\text { heat-energy-power system }\end{array}$ & 2019 \\
\hline [40] & WE & Demand response & $\begin{array}{l}\text { A review on demand response in } \\
\text { energy-water nexus }\end{array}$ & 2019 \\
\hline [41] & WEF & Financial impact of nexus & $\begin{array}{l}\text { An investigation of volatility spillover in } \\
\text { Europe, Asia, North America, Latin America } \\
\text { and the world is addressed }\end{array}$ & 2017 \\
\hline$[42]$ & WE & $\begin{array}{l}\text { Financial impacts of } \\
\text { nexus }\end{array}$ & $\begin{array}{l}\text { Analyzing the impact of agriculture and } \\
\text { energy prices on the water industry }\end{array}$ & 2018 \\
\hline [43] & $\mathrm{E}$ & Financial & Modeling future energy prices in EUA & 2011 \\
\hline$[44]$ & WF & $\begin{array}{l}\text { Environmental, social, } \\
\text { economical }\end{array}$ & $\begin{array}{l}\text { The microfinance funding model, } \\
\text { public-private cooperation, } \\
\text { using data-intensive methods such as climate } \\
\text { forecasting models for agriculture }\end{array}$ & 2015 \\
\hline
\end{tabular}

In addition, due to the great importance of this novel subject, different techniques have been adapted around the world on real case studies or projects to prove the effectiveness of this subject. Some of the significant studies are highlighted in Table 3. 
Table 3. Brief data on some highlighted real case studies on different nexus.

\begin{tabular}{|c|c|c|c|c|}
\hline Ref No. & Nexus & Aspects of Goal & Location & Year \\
\hline$[45]$ & WE & $\begin{array}{l}\text { Recovery of energy from } \\
\text { wastewater treatment plants }\end{array}$ & United States & 2010 \\
\hline [46] & WE & Energy consumption & Bangladesh & 2012 \\
\hline [47] & FEW & The impacts of nexus on tourism & The Mediterranean Region & 2014 \\
\hline [48] & FEW & $\begin{array}{l}\text { The impacts on nexus on } \\
\text { transboundary context }\end{array}$ & $\begin{array}{l}\text { The Euphrates-Tigris } \\
\text { river basin }\end{array}$ & 2015 \\
\hline [49] & FEW & Transboundary river & $\begin{array}{l}\text { Tonle Sap Lake, Mekong } \\
\text { River Basin }\end{array}$ & 2015 \\
\hline$[50]$ & WE & $\begin{array}{l}\text { Urban agglomeration based on } \\
\text { multiregional data }\end{array}$ & $\begin{array}{l}\text { Beijing-Tianjin-Hebei } \\
\text { region, China }\end{array}$ & 2016 \\
\hline$[51]$ & FEW & $\begin{array}{l}\text { The urban systems fundamental to } \\
\text { investigate the transboundary FEW }\end{array}$ & Delhi, India & 2017 \\
\hline [52] & WE & $\begin{array}{l}\text { Proposing the reference } \\
\text { resource-to-service } \\
\text { system framework }\end{array}$ & New York City & 2017 \\
\hline [53] & FEW & $\begin{array}{l}\text { System analysis and } \\
\text { interactive visualization }\end{array}$ & $\begin{array}{l}\text { The Great Ruaha River } \\
\text { of Tanzania }\end{array}$ & 2018 \\
\hline$[54]$ & WE & $\begin{array}{l}\text { A review of tools and methods or } \\
\text { assessment of macro WE nexus } \\
\text { is presented }\end{array}$ & $\begin{array}{l}70 \text { case studies over the } \\
\text { world are surveyed, and } 35 \\
\text { comprehensive macro-level } \\
\text { case studies are detailed in } \\
\text { levels of the city, regional, } \\
\text { national, transboundary }\end{array}$ & 2018 \\
\hline [55] & WE & $\begin{array}{l}\text { Investigating the } \\
\text { construction industry }\end{array}$ & $\begin{array}{l}\text { China's at the } \\
\text { provincial level }\end{array}$ & 2019 \\
\hline$[56]$ & $\begin{array}{l}\text { Climate, land, } \\
\text { energy and water } \\
\text { (CLEW) nexus }\end{array}$ & $\begin{array}{l}\text { Analyzing the energy } \\
\text { sustainability challenges }\end{array}$ & Lebanon & 2019 \\
\hline [57] & FEW & $\begin{array}{l}\text { Assessment of nexus by applying a } \\
\text { decision support technique }\end{array}$ & Saudi Arabia & 2019 \\
\hline [58] & FEW & $\begin{array}{l}\text { Investigating some direct and } \\
\text { indirect nexus at metropolitan } \\
\text { statistical areas }\end{array}$ & United States & 2019 \\
\hline [59] & FEW & $\begin{array}{l}\text { Applying the stochastic } \\
\text { multicriteria decision-making } \\
\text { (MCDM) technique for } \\
\text { investigating the desirability of } \\
\text { different energy } \\
\text { generation methods }\end{array}$ & Indonesia & 2019 \\
\hline [60] & FEW & $\begin{array}{l}\text { Presenting a toolbox for } \\
\text { interactive analysis }\end{array}$ & $\begin{array}{l}\text { At the country-level, } \\
\text { for specified categories }\end{array}$ & 2020 \\
\hline
\end{tabular}

\section{Nexus Committee, Conferences and Real Case Studies}

Various conferences, committees, projects and research highlights were organized around the world, relying on nexus. Table 4 shows brief information about the committee and gathering. 
Table 4. Committee and conference information about nexus.

\begin{tabular}{|c|c|c|c|c|}
\hline Name & Year & Title & Subject & Location \\
\hline $\begin{array}{l}\text { United Nations } \\
\text { University (UNU) }\end{array}$ & 1983 & $\begin{array}{l}\text { Food-Energy } \\
\text { Nexus Program }\end{array}$ & Food-energy interconnections & Brazil \\
\hline $\begin{array}{l}\text { United Nations } \\
\text { University (UNU) }\end{array}$ & 1984 & $\begin{array}{l}\text { Food, Energy } \\
\text { and Ecosystems }\end{array}$ & Food-energy interconnections & Brazil \\
\hline $\begin{array}{l}\text { United Nations } \\
\text { University (UNU) }\end{array}$ & 1986 & $\begin{array}{l}\text { Food-Energy } \\
\text { and Ecosystems }\end{array}$ & $\begin{array}{l}\text { Energy consumption patterns } \\
\text { and their effects on ecosystem } \\
\text { and agriculture }\end{array}$ & India \\
\hline World Bank & $\begin{array}{l}\text { The } \\
1990 \text { s }\end{array}$ & Water, food and trade & & \\
\hline $\begin{array}{l}\text { Columbia Water Center of } \\
\text { the Earth Institute at } \\
\text { Columbia University }\end{array}$ & 2000 & $\begin{array}{l}\text { Water-energy- } \\
\text { agriculture }\end{array}$ & $\begin{array}{l}\text { Water and climate interact with } \\
\text { food, energy, ecosystems } \\
\text { and urbanization }\end{array}$ & India \\
\hline $\begin{array}{l}\text { Kyoto World } \\
\text { Water Forum }\end{array}$ & 2003 & Virtual water & Water as a pillar in the nexus & japan \\
\hline Bonn Nexus Conference & 2011 & $\begin{array}{l}\text { Water, energy and food } \\
\text { security nexus, } \\
\text { Solutions for the } \\
\text { green economy }\end{array}$ & $\begin{array}{l}\text { Nexus challenge, Increase } \\
\text { policy coherence, end waste } \\
\text { and minimize losses }\end{array}$ & Germany \\
\hline Rio +20 & 2012 & Green economy & $\begin{array}{l}\text { Political outcome, } \\
\text { Sustainable Development }\end{array}$ & Brazil \\
\hline $\begin{array}{l}\text { United Nations } \\
\text { University Institute for } \\
\text { Integrated Management } \\
\text { of Material Fluxes and } \\
\text { Resources } \\
\text { (UNU-FLORES) }\end{array}$ & 2012 & Water, waste and soil & $\begin{array}{l}\text { Interdependencies of } \\
\text { environmental resources and } \\
\text { the interconnection } \\
\text { between compartments. }\end{array}$ & \\
\hline $\begin{array}{l}\text { United Nations Economic } \\
\text { and Social Commission } \\
\text { for Asia and the Pacific } \\
\text { (UN-ESCAP) }\end{array}$ & 2013 & Food-Energy-Water & $\begin{array}{l}\text { Water-energy-food nexus, } \\
\text { synergies and tradeoffs }\end{array}$ & $\begin{array}{l}\text { Asia and } \\
\text { the Pacific }\end{array}$ \\
\hline $\begin{array}{l}\text { Food and Agriculture } \\
\text { Organization (FAO) }\end{array}$ & 2013 & Food-Energy-Water & $\begin{array}{l}\text { International efforts to defeat } \\
\text { hunger and improve } \\
\text { local economies }\end{array}$ & \\
\hline Bonn Nexus Conference & 2014 & $\begin{array}{l}\text { Sustainability in the } \\
\text { water-energy-food } \\
\text { nexus }\end{array}$ & $\begin{array}{l}\text { Financial, institutional, } \\
\text { technical and intellectual } \\
\text { resource development for } \\
\text { nexus research and applications }\end{array}$ & Germany \\
\hline
\end{tabular}

\section{Nexus Challenges}

Given the broad scope of the FEW nexus, including its three large-scale systems, as well as its newness and capitalization of its wide-ranging discussions, there are significant challenges to its implementation. Different researchers have focused on some of these challenges, as well as some relevant solutions. Some of these items are addressed as follows:

Authors of [61] reflected recent research in stakeholder engagement regarding the nexus field. The paper outlined four main emerging concepts in this regard, including using the trans-disciplinary approaches for assessing as well as visualizing nexus, the understanding capacity of building and governance, accounting for inter-scalar and multi-relationships and investigating the implications of future socioeconomic, climatic and technological changes. The authors claimed that "it seems likely that without new trans-disciplinary approaches, there will continue to be poor coordination in addressing challenges across the water food and energy domains". 
The existence of some serious challenges in the issues of planning, operation and privatization in the current three separate subsystems of food, water, and energy and necessitate to present the practical, useful and economical solutions to these issues in the FEW nexus; needing some new laws and governance structures and mechanisms for implementing the nexus concept, needing to find some solutions to the consequences of implementing this integrated system, are the most challenging issues from the perspective of reference [62].

Zaidi et al. [63] addressed the water-energy nexus problems and alternatives focusing on machine learning contexts. They categorized various challenges as data challenges: missing data, spatiotemporal data, heterogeneity in data, data collection standards and data availability; and machine learning challenges: modeling spatiotemporal data, modeling in the presence of missing data, identifying outliers (including imperfect collection methods/sensors and extreme events). In addition, they categorized the machine learning techniques used in the energy-water nexus based on applying artificial neural networks (ANN), support vector machines (SVM), time-series analysis, regression, unsupervised learning (including Bayesian model averaging, random forests and hybrid models) and reinforcement learning in energy generation, energy use, water use, energy for water and water for energy. Furthermore, the authors detailed the machine learning alternatives for the energy-water nexus as mining patterns and relationships in data, addressing heterogeneity in data, predicting energy-water nexus variables, modeling unobserved variables, integration of models and deep learning.

Reference [64] outlined the directions for researchers, decision-makers or practitioners, as Identifying nexus methods as well as tools which are suitable for implementation in nexus approaches, creating a practical roadmap, distinguishing the targeted resources, structures and subsystems, deciding system constraints and boundaries, categorizing method types based on research objectives, determining the capabilities and drawbacks and limitations of existing techniques and tools, classifying bottom-up and top-down techniques, describing the uncertain data and uncertain modeling. Authors of [5] categorized the future studies in the nexus field as system boundary, data and modeling uncertainty, the essential mechanism of the nexus and the evaluation of coupled nexus systems even though internal and external impact analysis is of great importance in this regard.

In addition, introducing new concepts such as a smart city (SC), mainly in power systems, has forced the operators and planners to search for new secure and reliable solutions for implementing the Nexus missions. In this regard, the reliability and security of design, planning and operation concepts of different nexuses in SCs should be analyzed and investigated carefully [65].

Analyzing various references and studies related to the challenges of nexus systems, which some of them are mentioned above, shows that there are some significant challenges, as well as solutions in implementing the nexus systems. Table 5 summarizes some of these concepts.

Table 5. Some of the challenges and solutions for implementing nexus systems.

\begin{tabular}{ll}
\hline \multicolumn{1}{c}{ Challenges } & \multicolumn{1}{c}{ Solutions } \\
\hline $\begin{array}{l}\text { Lack of integrated policy and } \\
\text { legislation for the system }\end{array}$ & $\begin{array}{l}\text { Integrated policy-making such as integrated pricing in water and } \\
\text { energy fields, developing a model of agricultural complex and } \\
\text { industry proper allocation }\end{array}$ \\
\hline Data uncertainty & $\begin{array}{l}\text { Implementing the appropriate uncertainty modeling such as } \\
\text { stochastic programming, scenario generation, and so on. }\end{array}$ \\
\hline Large numbers of data for subsystems & Applying data-mining techniques \\
\hline System boundary & $\begin{array}{l}\text { Accurate detection of cases using precise and rapid identification } \\
\text { of subsystems }\end{array}$ \\
\hline Lack of sufficient standards and laws & $\begin{array}{l}\text { Forming committees comprising subdiscipline specialists to address } \\
\text { this gap }\end{array}$ \\
\hline Lack of efficient software platforms & Presenting multi-domain software \\
\hline
\end{tabular}




\section{Conclusions}

In this paper, an overview of the processes, methods, policies and interconnections of several resources was reviewed. Recent researches show the trend of societies to establish a comprehensive plan for handling energy, food and water consumption effectively. This paper implies a different nexus method relationship with inherent water, energy and food resource interactions approach considering political and environmental aspects. We reviewed the current state of research on nexus approaches. Food, energy and water systems are interconnected in such a way that one action in a system often affects the others. Therefore, centralized techniques to investigate, planning and operation should be integrated to reduce the side-effects and increase collaboration and synergism. A significant interconnection between these three subsystems and their direct impacts on environmental concepts, climate changes, socioeconomic, policy-making, etc., needs stakeholder engagement so that integrated management overall subsystems is concerned. This is essential for achieving the nexus objectives and gaining sustainable development. Planning and policy-making between the departments and organizations implemented to get a common point to require the discourse between stakeholders and the structures of conflicting objectives to fully cooperate and reduce the interference. As it was concluded, the main challenges for implementing this concept are categorized as lack of integrated policy and legislation for the system, data uncertainty and large numbers data of subsystems, system boundary, lack of sufficient standards and laws and lack of efficient software platforms.

Author Contributions: H.A.: Main idea, data collecting, classifications, conceptualization, methodology, wtitting the original and revised versios; M.S.: Conceptualization, methodology, wtitting the original and revised versios; B.M.-I.: Conceptualization, methodology, wtitting the original and revised versios. All authors have read and agreed to the published version of the manuscript.

Funding: This research received no external funding.

Conflicts of Interest: The authors declare no conflict of interest.

\section{References}

1. Albrecht, T.R.; Crootof, A.; Scott, C.A. The Water-Energy-Food Nexus: A systematic review of methods for nexus assessment. Environ. Res. Lett. 2018, 13, 043002. [CrossRef]

2. Griffith, D.; Johnson, D.; Hunt, A. The geographic distribution of metals in urban soils: The case of Syracuse, NY. GeoJournal 2009, 74, 275-291. [CrossRef]

3. Eftelioglu, E.; Jiang, Z.; Tang, X.; Shekhar, S. The nexus of food, energy, and water resources: Visions and challenges in spatial computing. In Advances in Geocomputation; Springer: Cham, Switzerland, 2017; pp. 5-20.

4. Bazilian, M.; Rogner, H.; Howells, M.; Hermann, S.; Arent, D.; Gielen, D.; Steduto, P.; Mueller, A.; Komor, P.; Tol, R.S. Considering the energy, water and food nexus: Towards an integrated modelling approach. Energy Policy 2011, 39, 7896-7906. [CrossRef]

5. Zhang, C.; Chen, X.; Li, Y.; Ding, W.; Fu, G. Water-energy-food nexus: Concepts, questions and methodologies. J. Clean. Prod. 2018, 195, 625-639. [CrossRef]

6. Sanders, K.T.; Webber, M.E. Evaluating the energy consumed for water use in the United States. Environ. Res. Lett. 2012, 7, 034034. [CrossRef]

7. Gutjahr, W.J. Convergence Analysis of Metaheuristics. In Matheuristics; Springer: Boston, MA, USA, 2009; pp. 159-187.

8. Bavafa, M.; Navidi, N.; Monsef, H. A new approach for Profit-Based Unit Commitment using Lagrangian relaxation combined with ant colony search algorithm. In Proceedings of the 2008 43rd International Universities Power Engineering Conference, Padova, Italy, 1-4 September 2008.

9. Rampriya, B.; Mahadevan, K. Scheduling the units and maximizing the profit of GENCOS using LR-PSO technique. Int. J. Electr. Eng. Inform. 2010, 2, 150-158. [CrossRef]

10. National Intelligence Council. Global Trends 2030: Alternative Worlds: A Publication of the National Intelligence Council; U.S. Government Printing Office: Washington, DC, USA, 2012.

11. Meadows, D.H.; Meadows, D.L.; Randers, J.; Behrens, W.W., III. The Limits to Growth: A Report for the Club of Rome's Project on the Predicament of Mankind; Universe Books: New York, NY, USA, 1972. 
12. Brouwer, F.; Avgerinopoulos, G.; Fazekas, D.; Laspidou, C.; Mercure, J.-F.; Pollitt, H.; Ramos, E.P.; Howells, M. Energy modelling and the Nexus concept. Energy Strategy Rev. 2018, 19, 1-6. [CrossRef]

13. Specht, K.; Siebert, R.; Hartmann, I.; Freisinger, U.B.; Sawicka, M.; Werner, A.; Thomaier, S.; Henckel, D.; Walk, H.; Dierich, A. Urban agriculture of the future: An overview of sustainability aspects of food production in and on buildings. Agric. Hum. Values 2014, 31, 33-51. [CrossRef]

14. Global Enerzgy Consumption to Increase by 50 by 2050. Available online: https://safety4sea.com/globalenergy-consumption-to-increase-by-50-by-2050/ (accessed on 18 November 2020).

15. Shahbazitabar, M.; Abdi, H. A novel priority-based stochastic unit commitment considering renewable energy sources and parking lot cooperation. Energy 2018, 161, 308-324. [CrossRef]

16. Wang, X.-C.; Klemeš, J.J.; Dong, X.; Fan, W.; Xu, Z.; Wang, Y.; Varbanov, P.S. Air pollution terrain nexus: A review considering energy generation and consumption. Renew. Sustain. Energy Rev. 2019, 105, 71-85. [CrossRef]

17. Endo, A.; Tsurita, I.; Burnett, K.; Orencio, P.M. A review of the current state of research on the water, energy, and food nexus. J. Hydrol. Reg. Stud. 2017, 11, 20-30. [CrossRef]

18. Bizikova, L.; Roy, D.; Venema, H.D.; McCandless, M.; Swanson, D.; Khachtryan, A.; Borden, C.; Zubrycki, K. Water-Energy-Food Nexus and Agricultural Investment: A Sustainable Development Guidebook; International Institute for Sustainable Development (IISD): Winnipeg, MB, Canada, 2014.

19. AKHAVAN KAZEMI, M.; Sadat Hoseini, T.; Bahramipoor, F. Analysis of the Impact of Climate Change on International Security. Res. Lett. Int. Relat. 2019, 12, 9-39.

20. Hellegers, P.; Zilberman, D.; Steduto, P.; McCornick, P. Interactions between water, energy, food and environment: Evolving perspectives and policy issues. Water Policy 2008, 10, 1-10. [CrossRef]

21. Mushtaq, S.; Maraseni, T.N.; Maroulis, J.; Hafeez, M. Energy and water tradeoffs in enhancing food security: A selective international assessment. Energy Policy 2009, 37, 3635-3644. [CrossRef]

22. Khan, S.; Hanjra, M.A. Footprints of water and energy inputs in food production-Global perspectives. Food Policy 2009, 34, 130-140. [CrossRef]

23. Maroufmashat, A.; Taqvi, S.T.; Miragha, A.; Fowler, M.; Elkamel, A. Modeling and Optimization of Energy Hubs: A Comprehensive Review. Inventions 2019, 4, 50. [CrossRef]

24. Di Somma, M.; Caliano, M.; Graditi, G.; Pinnarelli, A.; Menniti, D.; Sorrentino, N.; Barone, G. Designing of cost-effective and low-carbon multi-energy nanogrids for residential applications. Inventions 2020, 5, 7. [CrossRef]

25. Qadir, M.; Sharma, B.R.; Bruggeman, A.; Choukr-Allah, R.; Karajeh, F. Non-conventional water resources and opportunities for water augmentation to achieve food security in water scarce countries. Agric. Water Manag. 2007, 87, 2-22. [CrossRef]

26. Kumar, M.D.; Sivamohan, M.; Narayanamoorthy, A. The food security challenge of the food-land-water nexus in India. Food Secur. 2012, 4, 539-556. [CrossRef]

27. Akangbe, J.; Adesiji, G.; Fakayode, S.; Aderibigbe, Y. Towards palm oil self-sufficiency in Nigeria: Constraints and training needs nexus of palm oil extractors. J. Hum. Ecol. 2011, 33, 139-145. [CrossRef]

28. Hardy, L.; Garrido, A.; Juana, L. Evaluation of Spain's water-energy nexus. Int. J. Water Resour. Dev. 2012, 28, 151-170. [CrossRef]

29. Noruzi, M.; Yazdandoost, F. Determining the Optimal Point In Arid Basins Using Water-Energy Nexus Approach. Int. J. Optim. Civ. Eng. 2019, 9, 423-435.

30. Chakraborty, S. WATER-ENERGY NEXUS: ROLE OF SOLAR ENERGY. PREPARE@ U-Preprint Archive, 2019. [CrossRef]

31. Scott, C.A.; Pierce, S.A.; Pasqualetti, M.J.; Jones, A.L.; Montz, B.E.; Hoover, J.H. Policy and institutional dimensions of the water-energy nexus. Energy Policy 2011, 39, 6622-6630. [CrossRef]

32. Yang, H.; Yang, D.; Lei, Z.; Sun, F. New analytical derivation of the mean annual water-energy balance equation. Water Resour. Res. 2008, 44. [CrossRef]

33. Hang, M.Y.L.P.; Martinez-Hernandez, E.; Leach, M.; Yang, A. Designing integrated local production systems: A study on the food-energy-water nexus. J. Clean. Prod. 2016, 135, 1065-1084. [CrossRef]

34. Kibler, K.M.; Reinhart, D.; Hawkins, C.; Motlagh, A.M.; Wright, J. Food waste and the food-energy-water nexus: A review of food waste management alternatives. Waste Manag. 2018, 74, 52-62. [CrossRef]

35. Cai, X.; Wallington, K.; Shafiee-Jood, M.; Marston, L. Understanding and managing the food-energy-water nexus-opportunities for water resources research. Adv. Water Resour. 2018, 111, 259-273. [CrossRef] 
36. White, D.J.; Hubacek, K.; Feng, K.; Sun, L.; Meng, B. The Water-Energy-Food Nexus in East Asia: A teleconnected value chain analysis using inter-regional input-output analysis. Appl. Energy 2018, 210, 550-567. [CrossRef]

37. Jabari, F.; Mohammadi Ivatloo, B.; Sharifian, B.; Ghaebi, H. Day-ahead economic dispatch of coupled desalinated water and power grids with participation of compressed air energy storages. J. Oper. Autom. Power Eng. 2019, 7, 40-48.

38. Jabari, F.; Mohammadi Ivatloo, B.; Sharifian, B.; Ghaebi, H. Optimal Short-Term Coordination of Desalination, Hydro and Thermal Units. J. Oper. Autom. Power Eng. 2019, 7, 141-147.

39. Jabari, F.; Jabari, H.; Mohammadi-ivatloo, B.; Ghafouri, J. Optimal short-term coordination of water-heat-power nexus incorporating plug-in electric vehicles and real-time demand response programs. Energy 2019, 174, 708-723. [CrossRef]

40. Kirchem, D.; Lynch, M.Á.; Bertsch, V.; Casey, E. Modelling demand response with process models and energy systems models: Potential applications for wastewater treatment within the energy-water nexus. Appl. Energy 2020, 260, 114321. [CrossRef]

41. Peri, M.; Vandone, D.; Baldi, L. Volatility spillover between water, energy and food. Sustainability 2017, 9, 1071. [CrossRef]

42. Vandone, D.; Peri, M.; Baldi, L.; Tanda, A. The impact of energy and agriculture prices on the stock performance of the water industry. Water Resour. Econ. 2018, 23, 14-27. [CrossRef]

43. Peri, M.; Baldi, L. Nonlinear price dynamics between CO2 futures and Brent. Appl. Econ. Lett. 2011, 18, 1207-1211. [CrossRef]

44. Govardhan, M.; Mishra, M.; Sundeep, S.; Roy, R. Solution of price based unit commitment using GABC and TLBO optimization algorithms. In Proceedings of the 2014 International Conference on Control, Instrumentation, Energy and Communication (CIEC), Calcutta, India, 31 January-2 February 2014.

45. Stillwell, A.S.; Hoppock, D.C.; Webber, M.E. Energy recovery from wastewater treatment plants in the United States: A case study of the energy-water nexus. Sustainability 2010, 2, 945-962. [CrossRef]

46. Alam, M.J.; Begum, I.A.; Buysse, J.; Van Huylenbroeck, G. Energy consumption, carbon emissions and economic growth nexus in Bangladesh: Cointegration and dynamic causality analysis. Energy Policy 2012, 45, 217-225. [CrossRef]

47. Tugcu, C.T. Tourism and economic growth nexus revisited: A panel causality analysis for the case of the Mediterranean Region. Tour. Manag. 2014, 42, 207-212. [CrossRef]

48. Kibaroglu, A.; Gürsoy, S.I. Water-energy-food nexus in a transboundary context: The Euphrates-Tigris river basin as a case study. Water Int. 2015, 40, 824-838. [CrossRef]

49. Keskinen, M.; Someth, P.; Salmivaara, A.; Kummu, M. Water-energy-food nexus in a transboundary river basin: The case of Tonle Sap Lake, Mekong River Basin. Water 2015, 7, 5416-5436. [CrossRef]

50. Wang, S.; Chen, B. Energy-water nexus of urban agglomeration based on multiregional input-output tables and ecological network analysis: A case study of the Beijing-Tianjin-Hebei region. Appl. Energy 2016, 178, 773-783. [CrossRef]

51. Ramaswami, A.; Boyer, D.; Nagpure, A.S.; Fang, A.; Bogra, S.; Bakshi, B.; Cohen, E.; Rao-Ghorpade, A. An urban systems framework to assess the trans-boundary food-energy-water nexus: Implementation in Delhi, India. Environ. Res. Lett. 2017, 12, 025008. [CrossRef]

52. Engström, R.E.; Howells, M.; Destouni, G.; Bhatt, V.; Bazilian, M.; Rogner,H.-H. Connecting the resource nexus to basic urban service provision-with a focus on water-energy interactions in New York City. Sustain. Cities Soc. 2017, 31, 83-94. [CrossRef]

53. Yang, Y.E.; Wi, S. Informing regional water-energy-food nexus with system analysis and interactive visualization-A case study in the Great Ruaha River of Tanzania. Agric. Water Manag. 2018, 196, 75-86. [CrossRef]

54. Dai, J.; Wu, S.; Han, G.; Weinberg, J.; Xie, X.; Wu, X.; Song, X.; Jia, B.; Xue, W.; Yang, Q. Water-energy nexus: A review of methods and tools for macro-assessment. Appl. Energy 2018, 210, 393-408. [CrossRef]

55. Hong, J.; Zhong, X.; Guo, S.; Liu, G.; Shen, G.Q.; Yu, T. Water-energy nexus and its efficiency in China's construction industry: Evidence from province-level data. Sustain. Cities Soc. 2019, 48, 101557. [CrossRef]

56. Abou Farhat, R.; Mahlooji, M.; Gaudard, L.; El-Baba, J.; Harajli, H.; Kabakian, V.; Madani, K. A Multi-attribute Assessment of Electricity Supply Options in Lebanon. In Food-Energy-Water Nexus Resilience and Sustainable Development; Springer: Cham, Switzerland, 2020; pp. 1-27. 
57. Vittorio, M. A Decision Support Tool for the Assessment of Water-Energy-Food Nexus in Saudi Arabia. In Food-Energy-Water Nexus Resilience and Sustainable Development; Springer: Cham, Switzerland, 2020; pp. 57-73.

58. Djehdian, L.A.; Chini, C.M.; Marston, L.; Konar, M.; Stillwell, A.S. Exposure of urban food-energy-water (FEW) systems to water scarcity. Sustain. Cities Soc. 2019, 50, 101621. [CrossRef]

59. Mahlooji, M.; FGumilar, G.; Madani, K. Dealing with Trade-offs in Sustainable Energy Planning: Insight for Indonesia. In Food-Energy-Water Nexus Resilience and Sustainable Development; Springer: Cham, Switzerland, 2020; pp. 243-266.

60. Sadegh, M.; AghaKouchak, A.; Mallakpour, I.; Huning, L.S.; Mazdiyasni, O.; Niknejad, M.; FoufoulaGeorgiou, E.; Moore, F.C.; Brouwer, J.; Farid, A. Data and analysis toolbox for modeling the nexus of food, energy, and water. Sustain. Cities Soc. 2020, 61, 102281. [CrossRef]

61. Hoolohan, C.; Larkin, A.; McLachlan, C.; Falconer, R.; Soutar, I.; Suckling, J.; Varga, L.; Haltas, I.; Druckman, A.; Lumbroso, D. Engaging stakeholders in research to address water-energy-food (WEF) nexus challenges. Sustain. Sci. 2018, 13, 1415-1426. [CrossRef]

62. Larson, R.B.; Holley, C.; Bowman, D.M. THE ENERGY/WATER/FOOD NEXUS—AN INTRODUCTION. Jurimetr. J. Lawscience Technol. 2018, 59, 1-14.

63. Zaidi, S.M.A.; Chandola, V.; Allen, M.R.; Sanyal, J.; Stewart, R.N.; Bhaduri, B.L.; McManamay, R.A. Machine learning for energy-water nexus: Challenges and opportunities. Big Earth Data 2018, 2, 228-267. [CrossRef]

64. Endo, A.; Yamada, M.; Miyashita, Y.; Sugimoto, R.; Ishii, A.; Nishijima, J.; Fujii, M.; Kato, T.; Hamamoto, H.; Kimura, M. Dynamics of water-energy-food nexus methodology, methods, and tools. Curr. Opin. Environ. Sci. Health 2020, 13, 46-60. [CrossRef]

65. Abdi, H.; Shahbazitabar, M. Smart city: A review on concepts, definitions, standards, experiments, and challenges. J. Energy Manag. Technol. 2020, 4, 1-6.

Publisher's Note: MDPI stays neutral with regard to jurisdictional claims in published maps and institutional affiliations.

(C) 2020 by the authors. Licensee MDPI, Basel, Switzerland. This article is an open access article distributed under the terms and conditions of the Creative Commons Attribution (CC BY) license (http://creativecommons.org/licenses/by/4.0/). 